\title{
Nuclease Activity Associated with Secreting Granules by Lymphocytes in Patients with Bronchial Asthma
}

Cyrille Alode Vodounon $^{1 *}$, Zinaida Ivanovna Abramova ${ }^{2}$, Ylia Valerevna Skibo ${ }^{2}$, Irina Dmitrievna Reshetnikova ${ }^{3}$, Simon Ayeleroun Akpona ${ }^{1}$, Haziz Sina ${ }^{4}$ and Lamine Baba-Moussa ${ }^{4}$

${ }^{1}$ Laboratory of Biochemistry and Microbiology, Ecole Normale Superieure Natitingou (ENS), University of Parakou, Benin

${ }^{2}$ Department of Biochemistry and Microbiology, Laboratory of Nucleic Acids, Institute of Fundamental Medicine and Biology, Kazan Federal University (KFU-Russian), Ulitsa Kremlevskaya, 18, Kazan, Russia

${ }^{3}$ Kazan Research Institute of Epidemiology and Microbiology, ul.Bolshaya Krasnaya, 67 Kazan, Tatarstan 420015, Russia

${ }^{4}$ Department of Biology and Cell Biology, Laboratory of Molecular Typing and Microbiology, University of Abomey, Benin

*Corresponding author: Cyrille Alode Vodounon, Department of Biochemistry and Immunology, Laboratory of Biochemistry and Microbiology, Ecole Normale Superieure Natitingou (ENS), University of Parakou, Benin, Tel: 0022996668870; E-mail: sweetiebj@yahoo.fr

Received date: Septeber 30, 2015; Accepted date: December 14, 2015; Published date: December 21, 2015

Copyright: (c) 2015 Vodounon CA, et al. This is an open-access article distributed under the terms of the Creative Commons Attribution License, which permits unrestricted use, distribution and reproduction in any medium, provided the original author and source are credited.

\begin{abstract}
Background: We know, through recent studies, the existence of some morpho-biochemical peculiarities in the process of type 1 programmed death of patients' lymphocytes suffering from bronchial asthma, but little convincing data exist on the activity of enzymes involved in this physiological process. Therefore, the aim of our research was to study the enzymatic activity of secreting granules of patients' lymphocytes with bronchial asthma, according to the degree of severity.
\end{abstract}

Method: The study was based on the role of granular extracts in the process of programmed death isolated lymphocytes from peripheral blood of relatively healthy individuals and asthmatic patients with different severity. The immunological characteristics of lymphocytes was done with the radial immune-diffusion method and ELISA test but the method of agarose gel electrophoresis help us to detect the catalytic activity of protein extracts of secreting granules of lymphocytes.

Results: The results obtained showed that lymphocytes from asthmatic patients with severe severity are characterized by a decrease in cytotoxic T lymphocytes content balanced by an increase in T-Helper lymphocytes. We also noticed the enzymatic activity at all the groups studied but this activity was relatively high in asthmatics with severe severity. Furthermore, the study of the cationic dependence has allowed to establish an increase in enzymatic activity in all the groups studied after incubation of DNA in a medium containing $\mathrm{Ca}^{2+}$ with a pH of 7.5 unlike ions $\mathrm{Mn}^{2+}$ which seem to reduce the enzymatic activity. The expression of enzymatic activity in the presence of zinc allows us to suggest the presence of DNase acid in granules, which activity is not necessarily associated with divalent metal ions.

Conclusion: Based on the above results, one might conclude that the secreting granules have a high enzymatic activity but with a strong cationic dependence. This not only allows a better understanding of the morphological changes observed during the course of apoptosis in lymphocytes of patients but also brings more to the knowledge of the enzymatic influence in the process of type 1 programmed death.

Keywords: Granule; Apoptosis; Lymphocytes; Bronchial asthma

\section{Introduction}

The findings of recent years suggests the possibility of a common pathogenic pathway in the course of the development of atopy, allergy and autoimmunity, as these processes are interrelated by a perturbation of the functioning of immune system where lymphocytes play a central role [1-4]. These lymphocytes, although playing an important role in the immune response, are controlled by the process of programmed cell death (PCD) of type 1 [5-8]. Many researchers, including Zhivotovsky et al. [9,10] believe that the PCD of type 1 falls due owing to the enzymatic degradation of deoxyribonucleic acid in the cell nucleus. Thus, the DNA fragmentation is one of the most important biochemical signs in the process PCD of type 1 [11].
However, the role played by these enzymes involved in this process and their mechanism of action is misunderstood. The current data confirm the role of certain nucleases in PCD. Thus, some authors believe that the endonuclease $G$ released from mitochondria initiates DNA fragmentation and thereafter, this process of fragmentation is increased by DNase I released from necrotic cells. This process had its scope in necrosis of oncogenous hepatocytes [12,13]. Oliveri et al. first demonstrated in vivo that the enzyme activity of DNase $(\mathrm{Ca}, \mathrm{Mg}$ dependent) emerges in the cells exposed to apoptosis induced by drugs, and that performs the degradation of DNA at nucleosome level in human cells [14]. Lipskaya [15] and Meng et al. have shown activation of DNase (Ca, Mg-dependent), which is inhibited in the presence of zinc ions in the process PCD of type 1 [16]. Likewise, it was discovered another nuclease activity associated with secreting granules by cytotoxic monocytes of CD14+ and CD16+ phenotypes in 
patients with autoimmune diseases such as severe diseases and multiple sclerosis [17]. This DNase is more active on double-stranded DNA than on single-stranded DNA and differs from the other three types of endonucleases that are involved in DNA fragmentation (DNase I, DNase II, and NUC 18) [18]. According to author's, this nuclease is involved in the mechanism of programmed death or lysis of cytotoxic $\mathrm{T}$ lymphocytes and may be associated with a change of the autoimmune response that depends on $\mathrm{T}$ lymphocytes inducing apoptosis. So far, there is no conclusive data on the nature and role of nucleases involved in the process of programmed death of lymphocytes in asthmatic patients. Because of the ambiguity of the information available on the subject, we decided to study the enzymatic activity of secreting granules of lymphocytes in patients with bronchial asthma according to the degree of severity.

\section{Materials and Methods}

\section{Patients and blood sampling}

The study was carried out on the lymphocytes isolated from peripheral blood of relatively healthy donor and asthmatic individuals. Forty eight patients with an average age of $31 \pm 8$ years and 15 control donors who were not suffering from the bronchial asthma with an average age of $28 \pm 5$ years were studied. The group of patient consisted of people of different severity: 10 intermittents, 13 patients were mildly affected, 10 with moderate severity and 15 patients were severely affected. The severity of asthma in these patients was assessed according to the Global Initiation for Asthma guideline $[19,20]$. The diagnosis of the bronchial asthma was established on the basis of the data of allergic anamnesis, results of cutaneous experiments of skin with allergens and dust. All patients and controls had no other chronic diseases. All individuals were non-smokers, did not receive corticosteroids in the 2 weeks prior to recruitment for the study and were selected after informed oral consent had been obtained. All the patients had a history of intermittent chest tightness, wheezing or shortness of breath for at least 5 years prior to study participation consistent with the diagnosis of asthma according to Global Initiative for Asthma. None of the individuals had any respiratory infections in the month previous to their inclusion in the study. No other clinically relevant diseases were reported. The blood was taken from the veins of donors in the morning before their breakfast. Eight $\mathrm{ml}$ of peripheral blood was taken in a specialized tube containing heparin-Na (EUROTUBO, Spain) from each patient and control subject. The work was performed in accordance with the rules of the Ethics Committee in the laboratory of Clinical Immunology and Allergy of RKB and with the regulations of the Ministry of Health of the Russian Federation in compliance with the Helsinki Declaration.

\section{Isolation of lymphocytes}

Peripheral blood lymphocytes were isolated by the method of zonal centrifugation on a density gradient $(3000 \mathrm{rpm} / \mathrm{min}, \mathrm{K}-24)$ ficollverografine $(\rho=1.077 \mathrm{~g} / \mathrm{cm})$ [21,22]. Lymphocyte suspension was washed and collected after centrifugation at $2000 \mathrm{rpm} / \mathrm{min}$ for $10 \mathrm{~min}$ at $20^{\circ} \mathrm{C}$. This method was used to isolate at least $95 \%$ of T- lymphocytes according to the data from Patel et al. [23]. The viability of lymphocytes was determined by the trypan blue exclusion method [24-26]. To obtain a pure population of T lymphocytes, we used the negative isolation method with the use of super paramagnetic beads
CD3 (Dynabeads CD3, Dynal, Invitrogen) [27]. The cell populations were analyzed with the flow cytometer FACSCalibur (Becton Dickinson, CШA) with the use of Cell Quest and MultiSet software (Becton Dickinson). The cell staining was performed with a dual combination of four colors monoclonal antibody in form of Multitest IMK kit (Becton Dickinson): CD3+; CD8+; CD45+; И CD4+CD3+; CD16+; CD56+; CD45+; CD19+ in accordance with the protocol proposed by the manufacturer. The dosage of immunoglobulin in serum was done with the radial immune-diffusion method and ELISA test was used to determine the levels of IgE.

\section{Obtaining of secreting granules}

The secreting granules were isolated from lymphocytes by the method proposed by Podack et al. [28] on gradient of percoll density. For the preservation of the structure of lymphocytes and the obtaining of secreting granules, the lymphocytes were rinsed in $0.32 \mathrm{M}$ of sucrose solution in a buffer solution prepared from $0.01 \mathrm{M}$ Tris- $\mathrm{HCl}(\mathrm{pH}=7.2)$ and containing $0.003 \mathrm{M}$ of $\mathrm{CaCl}_{2}$. After centrifugation at $5000 \mathrm{rpm} /$ min for $20 \mathrm{~min}, 1 \mathrm{ml}$ of buffer solution of $0.01 \mathrm{M}$ Tris- $\mathrm{HCl}$ at $\mathrm{pH} 7.3$ was added to the pellet obtained. Suspend the cells and transfer them to a glass tube of Potter. Grinding the cells in the homogenizers with piston of Potter for $2 \mathrm{~min}$ in an ice bath, then add $3 \mathrm{ml}$ of buffer of 0.01 $\mathrm{M}$ Tris- $\mathrm{HCl}$ solution and incubated for $30 \mathrm{~min}$ in an ice bath. Centrifuging the homogenate for $15 \mathrm{~min}$ at $2300 \mathrm{rpm} / \mathrm{min}$ and at $4^{\circ} \mathrm{C}$. Collect the supernatant and wash the pellet with a buffer solution of $0.01 \mathrm{M}$ Tris-buffer and centrifuge again for $15 \mathrm{~min}$ at $2300 \mathrm{rpm} / \mathrm{min}$ (K-24). Collect again the supernatant. Once again the procedure is repeated, after which the supernatants were gathered for eventual extraction of the granules. The granules was obtained according to Percoll density gradient $(\rho=1.080 \mathrm{~g} / \mathrm{cm})$. Five (5) $\mathrm{ml}$ of the supernatant obtained was deposited on Percoll gradient and centrifuged at 19,500 $\mathrm{rpm} / \mathrm{min}$ for $35 \mathrm{~min}$ with the Beckman centrifuge. After centrifugation we recovered on $2 \mathrm{ml} \mathrm{5-7}$ fractions. For the elimination of Percoll gradient these fractions were centrifuged at $45000 \mathrm{rpm} / \mathrm{min}$ for 2.5 hours at $4^{\circ} \mathrm{C}$. There was formation of a whitish supernatant containing secreting granules.

\section{Revelation of the catalytic activity of granule extracts}

The granules of lymphocytes of asthmatic donors and nonasthmatics were incubated with DNA for 12 hours at $37^{\circ} \mathrm{C}$. Take aliquots and add a mixture containing $10 \%$ SDS-Na, 0.1\% BPB, $50 \%$ glycerin to stop the reaction. Allow these aliquots to migrate on a $1 \%$ agarose gel for 3 hours at a voltage of $5 \mathrm{~V} / \mathrm{cm}$. The results of the reaction were recorded using a video system "DNA Analyzer" (НПФ "Литех", Russia).

\section{Data analyses}

For quantitative and qualitative analysis of the activity of granule extracts, the gels were scanned and the results were processed with the "Scion image" program [29]. The fluorescence intensity of each area was compared with the total fluorescence intensity for each path considered as $100 \%$. This gives the possibility to define fragmentation index (FI) of DNA for each test and compare the nuclease activity of the different groups studied. In each case the results were compared with a blank as a control where DNA was incubated without protein extracts. We also used the excel package to analyze the data obtained. 
Citation: Vodounon CA, Abramova ZI, Skibo YV, Reshetnikova ID, Akpona SA, et al. (2015) Nuclease Activity Associated with Secreting Granules by Lymphocytes in Patients with Bronchial Asthma. Biol Med (Aligarh) 8: 264. doi:10.4172/0974-8369.1000264

Page 3 of 7

\section{Results}

\section{Immunological particularity of lymphocytes}

$\mathrm{T}$ lymphocytes play an undeniable role in the pathogenesis of bronchial asthma because of the importance of their number. One reason for the extension of the performance of this sub-population of cells is their stability to the process of programmed cell death of type 1. Therefore, we analyzed the level of $\mathrm{T}$ lymphocyte in the peripheral blood of donors studied. The comparative analysis of the results showed no significant difference in the level of $\mathrm{T}$ lymphocyte of the groups studied (Figure 1). According to the literature, T lymphocytes are divided into auxiliary $\mathrm{T}$ lymphocytes and cytotoxic $\mathrm{T}$ lymphocytes. The analysis of the level of T lymphocytes' subpopulations showed that the group patients with serious severity is characterized by a decrease in cytotoxic $\mathrm{T}$ lymphocytes content balanced by an increase in $\mathrm{T}$ Helper lymphocytes (Figure 1).

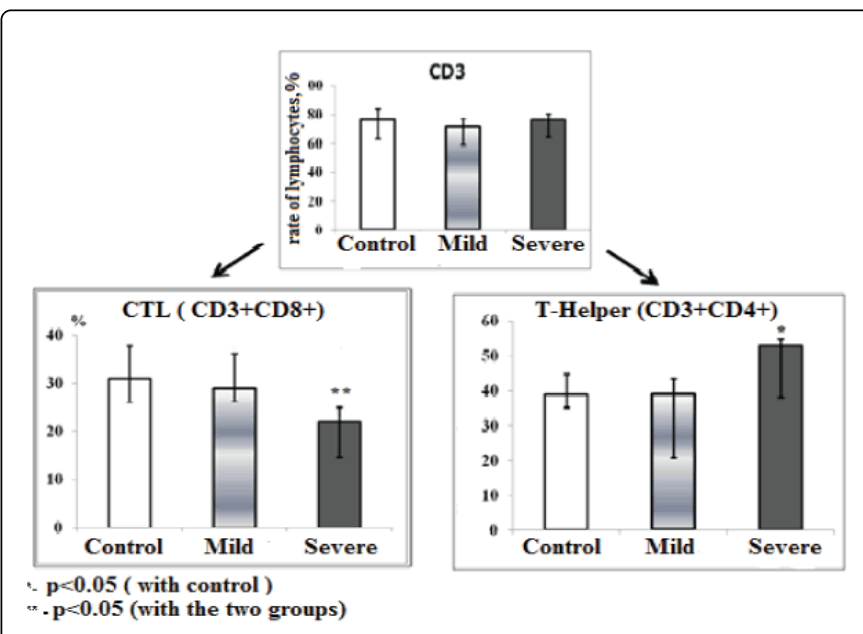

Figure 1: Content of T-lymphocytes in the peripheral blood of relatively healthy donors (control) and of bronchial asthmatic patients with mild and severe severity.

The increase in auxiliary T lymphocytes leads to an increase of the B lymphocytes which differentiate into plasmocytes capable of secreting immunoglobulin (Figure 2). The analysis of the immunoglobulin revealed a significant increase in IgE levels, which would indicate a high probability of the path of allergic process. The increase in the level of T CD4 lymphocytes and B lymphocytes in the group of patients with serious severity (Figure 2) suggests the involvement of humoral adaptive immunity in the pathogenesis of the disease. As any change in functional status is reflected on cell morphology we then set an objective for the next stage, the study of the catalytic activity of granular extracts of lymphocytes of different patient groups selected.

\section{Catalytic activity of granule secreted}

The secreting granules extracted from lymphocytes were incubated with the genomic DNA of Hedgehog Sea $(50 \mu \mathrm{g} / \mathrm{ml})$ in $20 \mathrm{mM}$ of buffer solution Tris- $\mathrm{HCl}$ at $\mathrm{pH} 7.5$ containing $50 \mathrm{mM} \mathrm{Mg}^{2+}$ for 12 hours. Therefore, the presence of the enzymatic activity of protein extracts in samples of relatively healthy donors and patients with bronchial asthma according to their degree of severity was established. Figure 3 shows the electrophorogram of DNA and the graph illustrating the variation in the enzymatic activity of the different groups studied.

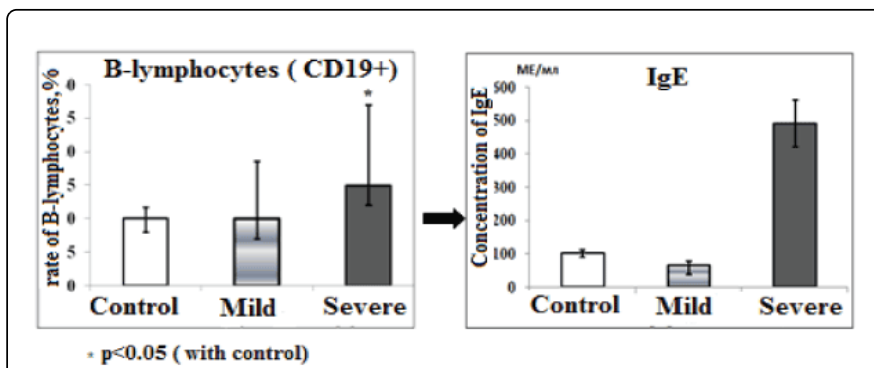

Figure 2: Indicator of humoral immunity of patiemts of relatively healthy donors and of bronchial asthmatic patients with mild and severe severity.

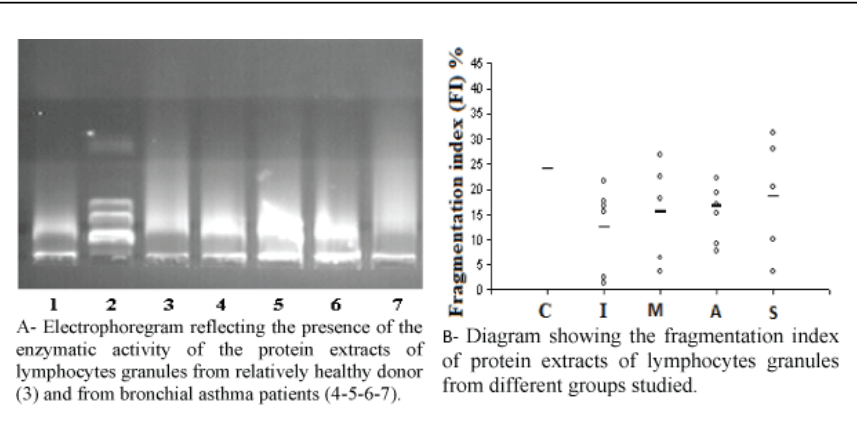

Figure 3: Enzymatic activity of protein extracts of lymphocytes' granules of different groups studied. Incubation of protein extract of lymphocytes' granules $(350 \mu \mathrm{g})$ with genomic DNA $(50 \mu \mathrm{g})$ in 20 $\mathrm{mM}$ of buffer solution Tris- $\mathrm{HCl}$ at $\mathrm{pH} 7.5$ containing $50 \mathrm{mM} \mathrm{Mg}^{2+}$. Well 1: DNA non-incubated - 2: Marker HindIII-digested phage DNA -3: Incubation of DNA with protein extracts of lymphocytes from non-asthmatic donors (C). Wells 4-7: enzymatic activity of protein extracts of lymphocytes from patients with bronchial asthma of intermittent severity (I), and mild persistent severity (M), moderate (A) and severe (S) respectively. IF: fragmentation index average value of the fragmentation index of the different groups studied. The time of incubation was 12 hours.

High enzymatic activity of secreting granules of lymphocytes in all groups studied was observed, but this activity was relatively high in healthy donors and asthmatics with grave severity. The individual parameters were characterized by the dispersion (Figure $3 b$ ) and probably reflect the immune status of each patient. From the results obtained, a difference in activity between the granular extracts of lymphocyte from relatively healthy donors and asthmatics was recorded in the presence of $\mathrm{Mg}^{2+}$ ions considered as an activator of enzymes especially nucleases. This difference was also observed when taking into account the degree of severity. Does the enzymatic activity of these granules depend upon the presence of $\mathrm{Mg}^{2+}$ ions? To answer this question we studied the behavior of the granular extracts lymphocytes from patients, i.e. the identification of the cationic 
Citation: Vodounon CA, Abramova ZI, Skibo YV, Reshetnikova ID, Akpona SA, et al. (2015) Nuclease Activity Associated with Secreting Granules by Lymphocytes in Patients with Bronchial Asthma. Biol Med (Aligarh) 8: 264. doi:10.4172/0974-8369.1000264

Page 4 of 7

dependence, the influence of inhibitors $\left(\mathrm{Zn}^{2+}\right)$ and $\mathrm{pH}$ of the medium. We noticed an increase of the enzymatic activity at all the groups studied after incubation of the DNA in a medium containing $\mathrm{Ca}^{2+}$ and at a $\mathrm{pH}$ of 7.5 (Figures 4-6). This experiment was repeated several times and in all cases there was a high degree of enzymatic activity after adding $1 \mathrm{mM} \mathrm{Ca}^{2+}$ in the reactional medium and this activity decreases as the concentration of $10 \mathrm{mM} \mathrm{Ca}^{2+}$ increased as well in non-asthmatic donors (Figure 4) as in patients with grave severity (Figure 5) and mild severity (Figure 6).

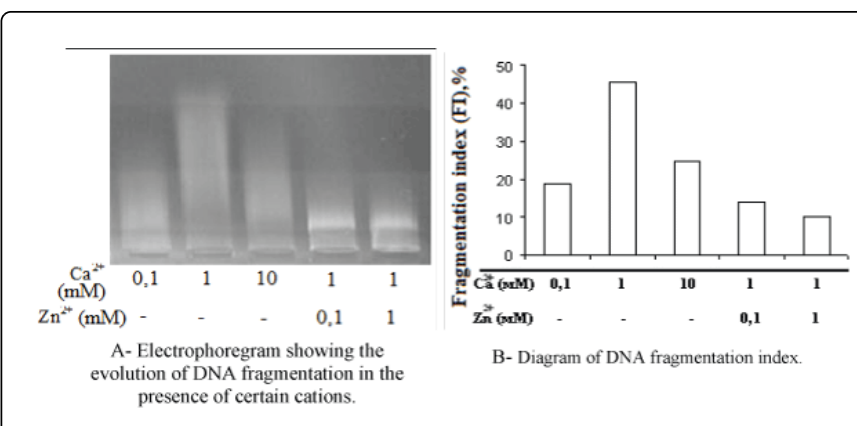

Figure 4: Cationic dependence of enzymatic activity of protein extracts of lymphocytes' granules from non-asthmatic donors. Incubating native DNA $(40 \mu \mathrm{g})$ of hedgehog sea in $20 \mathrm{mM}$ of buffer solution Tris- $\mathrm{HCl}$ at $\mathrm{pH} 7.5$ containing $50 \mathrm{mM} \mathrm{Mg}^{2+}$ with the addition of corresponding concentrations of $\mathrm{Ca}^{2+}$ and $\mathrm{Zn}^{2+}$ ions. The incubation time: 12 hours.

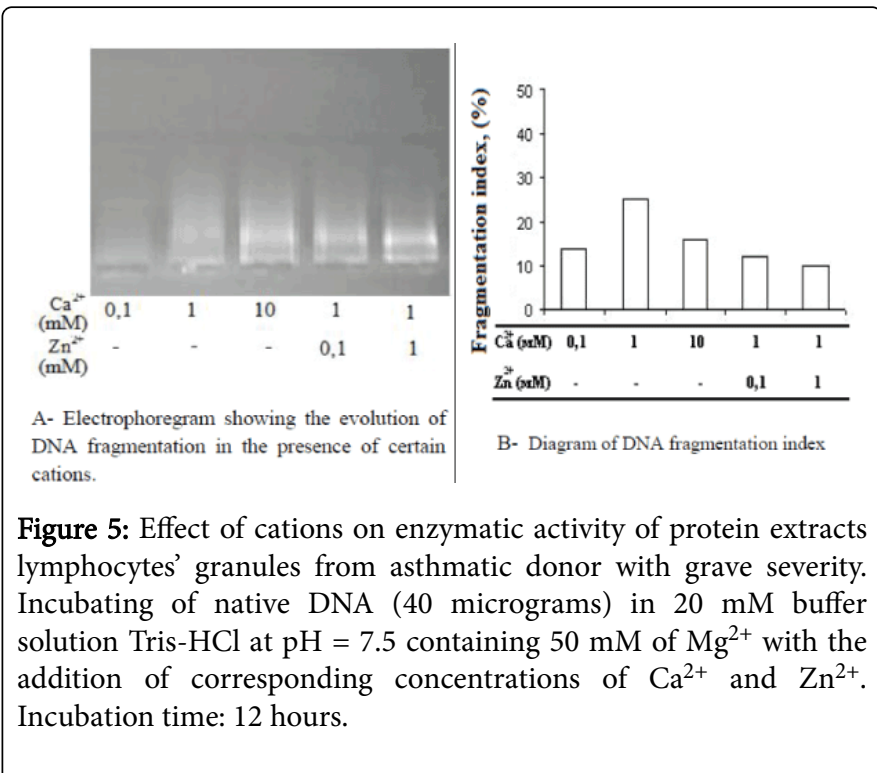

The results obtained show that fragmentation index of granular extracts in healthy donors (Figure 4B) was higher than in asthmatic patients with grave severity (Figure 5B) and mild (Figure 6B). The addition of $1 \mathrm{mM}$ of $\mathrm{Zn}^{2+}$ led to the inhibition of the enzymatic activity of granular extracts of lymphocytes by $73 \%$ in non-asthmatics (Figure $4 \mathrm{~B}$ ) and $45 \%$ in asthmatics with grave severity (Figure 5B) and about $50 \%$ in asthmatics of mild severity (Figure $6 \mathrm{~B}$ ). Thus, it should be noted that $\mathrm{Zn}^{2+}$ ions had an inhibitory action on granular extracts of lymphocytes of different groups studied, but it was low in asthmatics (Figures 5 and 6) compared with that observed in non-asthmatics (Figure 4).

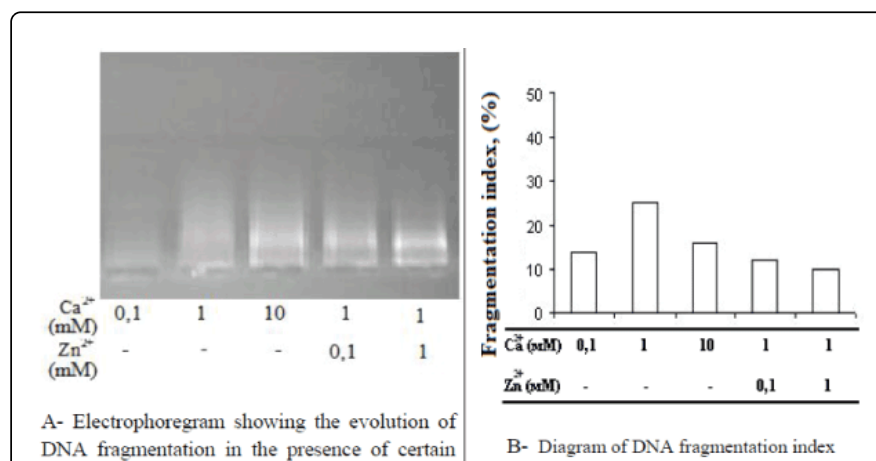

Figure 6: Effect of cations on enzymatic activity of protein extracts lymphocytes' granules from asthmatic donor with mild severity. Incubating of native DNA (40 micrograms) in $20 \mathrm{mM}$ buffer solution Tris- $\mathrm{HCl}$ at $\mathrm{pH}=7.5$ containing $50 \mathrm{mM}$ of $\mathrm{Mg}^{2+}$ with the addition of corresponding concentrations of $\mathrm{Ca}^{2+}$ and $\mathrm{Zn}^{2+}$. Incubation time: 12 hours.

To study the $\mathrm{pH}$ influence of the medium, we carried out a series of experiments on granular extracted from peripheral blood lymphocytes of patients with mild and grave severity (Figure 7) by varying the $\mathrm{pH}$ of the medium (pH.8, pH.7, pH.6). DNA fragmentation was determined in $\mathrm{pH} 8.0,7.0$, and 6.0 in the presence of $\mathrm{Mg}^{2+}$ only (Figure 7A) and $\mathrm{Mg}^{2+}$ and $\mathrm{Ca}^{2+}$ ions (Figure $7 \mathrm{~B}$ ).

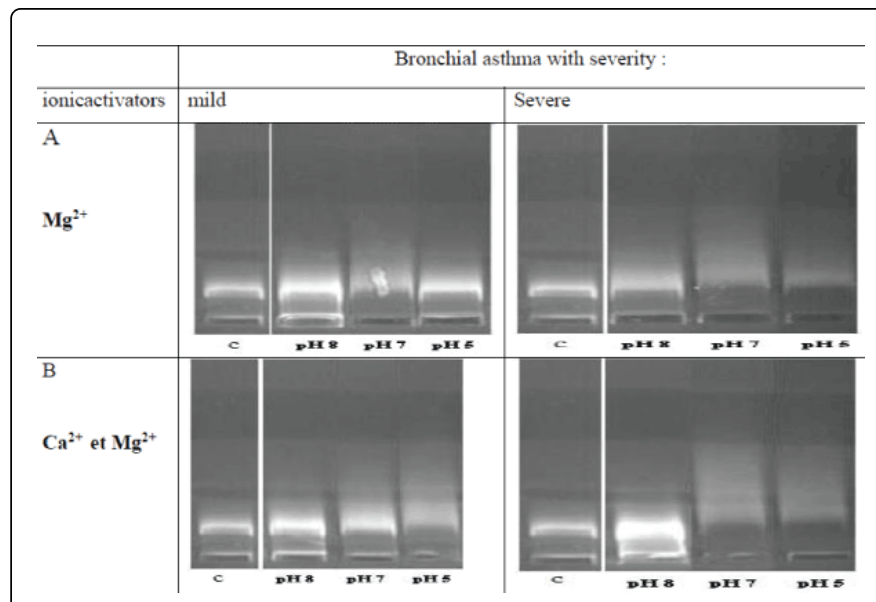

Figure 7: Electropherogram showing the influence of $\mathrm{pH}$ of the medium on catalytic activity of protein extracts from lymphocytes of asthmatics suffering from Mild and Severe severity with DNA in a buffer solution containing $50 \mathrm{mM}$ of $\mathrm{Mg}^{2+}$ ions and $\mathrm{Ca}^{2+}$ ions (1 $\mathrm{mM}$ ) (A) and only (50 $\mathrm{mM})$ of $\mathrm{Mg}^{2+}(\mathrm{B})$.

For each test we quantified the degree of enzymatic activity by the fragmentation index (Figure 8). 


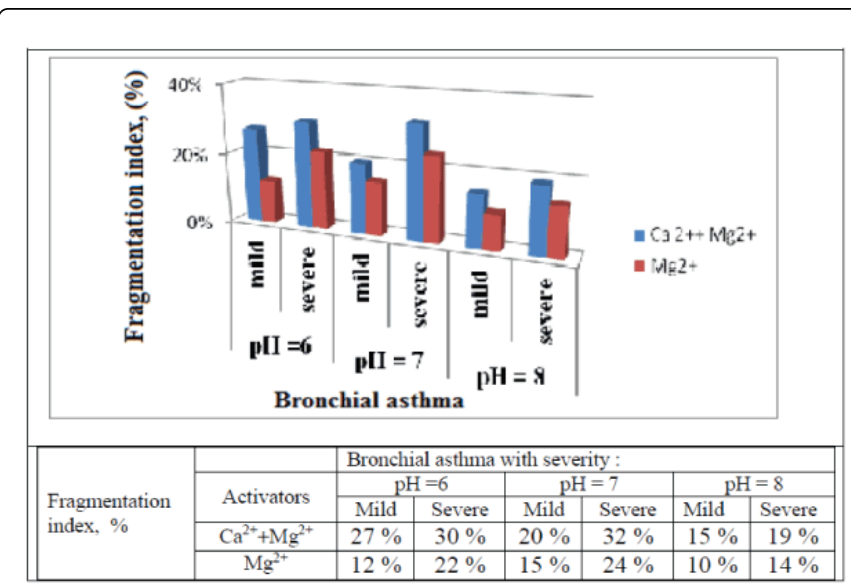

Figure 8: Fragmentation index shows the influence of the $\mathrm{pH}$ of the medium on enzymatic activity of protein extracts from lymphocytes' granules of patients with bronchial asthma of Mild and Severe severity in the presence of $\mathrm{Mg}^{2+}$ ions and $\mathrm{Ca}^{2+}$ and $\mathrm{Mg}^{2+}$ ions.

Protein extracts of granular activity was high among different groups studied at acidic $\mathrm{pH}$ of the medium in the presence of $\mathrm{Ca}^{2+}$ and $\mathrm{Mg}^{2+}$ and in the presence of $\mathrm{Mg}^{2+}$ only that a high enzymatic activity at a $\mathrm{pH}$ of 7.0 especially in asthmatics with severe severity was observed. At $\mathrm{pH}$ of 6 and after addition of $\mathrm{Ca}^{2+}$ in the medium there was an increase of enzymatic activity in asthmatics of severe severity based on the acidity of the medium, but the fragmentation index reached its maximum at $\mathrm{pH}$ 7. 0 . It is not excluded that this activity is related to the manifestation of other forms of nuclease activity, that is why we studied the enzymatic activities of these protein extracts in the presence of $\mathrm{Mn}^{2+}$ ions $(25 \mathrm{mM}), \mathrm{Ca}^{2+}$ ions $(1 \mathrm{mM})$ in a buffer solution of $20 \mathrm{mM}$ Tris-HCl-buffer at $\mathrm{pH}$ 7.5. As shown in Table 1, in the presence of $\mathrm{Mn}^{2+}$ ions the enzymatic activity of granular extracts was low, however, there was synergistic action which was several times higher after an additional $\mathrm{Ca}^{2+}$.

\begin{tabular}{|l|l|l|l|l|}
\hline \multirow{2}{*}{ Degree of severity $€$} & \multicolumn{4}{|c|}{ Ions activators } \\
\cline { 2 - 5 } & $\mathrm{Mn}^{2+}$ & $\mathrm{Mg}^{2+}$ & $\mathrm{Mn}^{2+}+\mathrm{Ca}^{2+}$ & $\mathrm{Mg}^{2+}+\mathrm{Ca}^{2+}$ \\
\cline { 2 - 5 } & Fragmentation Index (FI, \%) \\
\hline Mild & $12,5 \%$ & $16,0 \%$ & $27,7 \%$ & $19,4 \%$ \\
\hline Severe & $20,3 \%$ & $23,5 \%$ & $41,7 \%$ & $31,4 \%$ \\
\hline Variation of F.I.\% De: & $62,4 \%$ & $46,0 \%$ & $50,5 \%$ & $61,0 \%$ \\
\hline
\end{tabular}

Table 1: Fragmentation Index in \% showing the variation in the catalytic activity of the extracts of lymphocytes' granules from patients with bronchial asthma of mild and severe severity in synergy with some ions.

The addition of $\mathrm{Ca}^{2+}$ to the incubation medium in the presence of $\mathrm{Mg}^{2+}$ ions causes an increase of enzymatic activity both in asthmatics of mild severity (22\%) and grave severity (33.6\%). On the other hand, the addition of $\mathrm{Ca}^{2+}$ to the incubation medium containing $\mathrm{Mn}^{2+}$ ions causes an increase of $121 \%$ in asthmatics of mild severity and $105 \%$ in asthmatics of grave severity. From the results, we can assume that during the development of disease severity there was an increase in granular activity of $\mathrm{Mn}^{2+}$-dependent (fragmentation index increased by $62.4 \%)$ and $\mathrm{Ca}^{2+}$ and $\mathrm{Mg}^{2+}$ - dependent $(\mathrm{FI}=61 \%)$. After studying the behavior of granular extracts of lymphocytes from asthmatics donors and non-asthmatics on the genomic DNA of the sea hedgehog we underlined the sensitivity of the granular extracts of plasmid DNA (Figure 9) which has the particularity to present itself in a linear, circular and super-coiled shape.

Granular extracts of patients substantially hydrolyze DNA to obtain plasmid DNA in a linear shape through the circular shape (Figure 7). And after 2 hours after the start of the reaction, the rate of plasmid DNA did not increase in a linear shape substantially compared to the amount of linear DNA obtained after one hour of incubation, but there is a more stability of activity in the presence of $\mathrm{Zn}^{2+}$ ions. The enzymatic activity is more pronounced in asthmatic of severe severity by referring to the percentage rate of DNA obtained. During our work with granular extracts of lymphocyte there was a case of the expression of protein activity of the extracts in the presence of $\mathrm{Zn}^{2+}$ ions where $\mathrm{Zn}^{2+}$ ions behaved rather as activators of endogenous activity of nucleases. The use of pBR322 plasmid DNA as a substratum showed that the extract of granules in patients exhibits nuclease activity which is specific for cleavage of single-strands, since circular form in double strands (II) was stable enough to its action, and was not sensitive to $\mathrm{Zn}^{2+}$ ions as inhibitor.

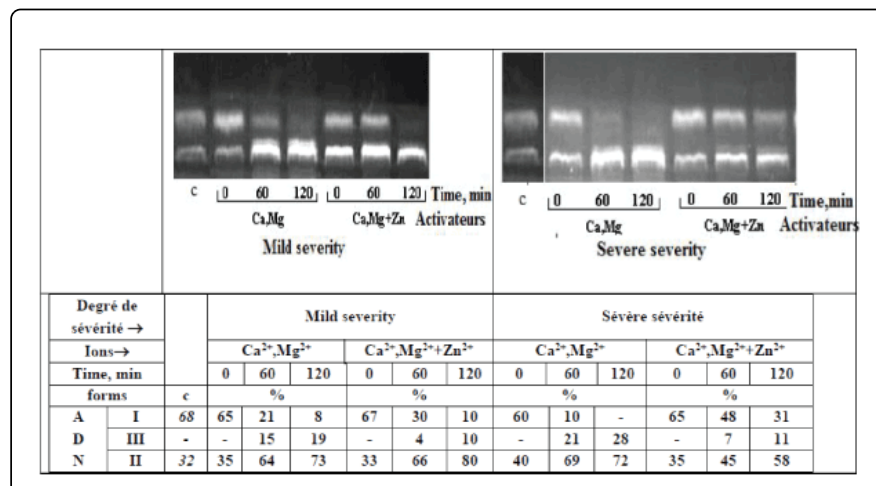

Figure 9: Electrophoregram of quantitative and qualitative estimation (\%) of the reaction products after hydrolysis of pBR322 DNA by protein extracts from patients with bronchial asthma of mild and severe severity in the presence of $\mathrm{Ca}^{2+}, \mathrm{Mg}^{2+}$ and $\mathrm{Ca}^{2+}$, $\mathrm{Zn}^{2+}+\mathrm{Mg}^{2+}$.

\section{Discussion}

The functionality and duration of bronchial asthma allow suggesting that one of the reasons for the chronicity of the disease is slowdown of the elimination of lymphocytes of the lungs. An analysis of previous studies on lymphocytes of patients with bronchial asthma showed the stability of these cells in the process of programmed death, which corollary is the slowdown of DNA fragmentation [30-32]. It is not excluded that this is due to the action of nucleases contained in peripheral blood lymphocytes of patients with asthma. Currently, there is convincing evidence of the existence of deoxyribonuclease involved in the apoptotic process [33]. According to some authors [34] there are two types of DNases involved in PCD 1 during the morphogenetic process in animals: DNase-dependent on metal ions $\mathrm{CMn}^{2+}$ and $\mathrm{Ca}^{2+}$, $\mathrm{Mg}^{2+}$ ) and DNases-independent on metal ions. For other authors, 
DNases involved in apoptosis may be classified into three groups: the $\mathrm{Ca}^{2+} / \mathrm{Mg}^{2+}$ endonucleases, the $\mathrm{Mg}^{2+}$ endonuclease, and the cationindependent endonucleases [33]. Recombinant human DNase I has been developed clinically for treatment of pulmonary disease in patients with cystic fibrosis [35]. DNase I is also under consideration for a variety of other diseases, including pediatric lung diseases other than cystic fibrosis [36], systemic lupus erythematosus [37,38] and cancer [39]. According to Nevinsky et al. [40] the deoxyribonucleases are very important in the process of metabolism of nucleic acids and for maintaining the physiological concentration of DNA in the living organism [40-42]. Several studies have shown that DNase as well as the antibodies hydrolyzing DNA can be used successfully in the diagnosis of various diseases. We observed the presence of multiple DNase in lymphocytes. Khodarev et al. have shown that DNase $\mathrm{Ca}^{2+}, \mathrm{Mg}^{2+}$ dependent on nucleus of lymphocytes of normal persons cleave plasmids specifically at defined locations [43]. Our data showed that the granular extracts of lymphocyte have an enzymatic activity in the presence of $\mathrm{Ca}^{2+}$ ions, $\mathrm{Mg}^{2+}$, which is consistent with the results of Pio et al. where the granular extract hydrolyzes pBR 322 DNA with an accumulation of the circular shape with time [13]. The zinc influences this hydrolysis reaction of granular proteins of lymphocytes and its role may vary from induction to inhibition, according to the severity degree of asthma. Moreover, Pio et al. showed the existence in monocytes of nuclease similar to that found in the lymphocytes from asthmatics, and which is inactivated by $\mathrm{Zn}^{2+}$ ions but whose activity increases with decreasing $\mathrm{pH}$ of the medium [13]. This DNase occurred in the fragmentation of DNA during the process of programmed death of type 1 , and was linked to an increase of $\mathrm{Ca}^{2+}$ ions and chelated complex associated with intracellular $\mathrm{Zn}^{2+}$ ions. Thus, in our present work, the expression of enzymatic activity in the presence of zinc allows us to suggest the presence of DNase acid in granules, which activity is not necessarily associated with divalent metal ions. There are data on the possibility of the involvement of the DNase activity of Tlymphocytes not only in the DNA fragmentation induced by cytotoxic $\mathrm{T}$ lymphocytes (CTL) to target cells, but also in the process of programmed death of type 1 of these cytotoxic cells (CTL). This idea coincides with the observations that the increase of the DNA fragmentation occurring in thymocytes, which is in relation with an increase in intracellular $\mathrm{Ca}^{2+}$ and $\mathrm{Zn}^{2+}$ ions from CTL cells. Furthermore, the granular constituents of CD8 lymphocytes CTLgranules, such as TIA-1 RNA-binding proteins have been described as part of the molecular processes involved in the cascading of programmed death of type 1 Fas-dependent. On the other hand, there are data which stipulate that the CD4 cytotoxic T-lymphocytes, inducing apoptosis in some cells (HLA-II ARC), may be directly involved in the mechanism of tissue destruction. And the answer to this abnormality occurs in autoimmune diseases. In addition, it was also found that the sub-population of CD16 and CD14 cells and DNases associated with monocytes increased in patients with some autoimmune diseases (grave disease, multiple sclerosis). It has been established that cytotoxic monocytes play an important role in tissue destruction as NO in the DNA fragmentation and cause an increase in the activity of the DNase in CD14 CD16 subpopulations potentially cytotoxic.

In summary our data show that nuclease was present in granules of lymphocytes freshly obtained from patients with bronchial asthma and may suggest that this enzyme could play some role in the programmed death of lymphocytes. This not only allows a better understanding of the morphological and biochemical changes observed during the course of apoptosis in lymphocytes of patients but also brings more to the knowledge of the enzymatic influence in the process of type 1 programmed death. All this might be used for the diagnosis of asthma with a better accuracy on the prognosis of the severity degree.

\section{Author's contribution}

ZIA, CAV, LBM designed the study. CAV, YVS, IDR, SAA participated in the technical work and the acquisition and interpretation of data. HS, SAA, CAV evaluated the literature. CAV, ZIA, IDR, YVS carried out the experiments of this study. LBM, HS, SAA, and ZIA have given final approval of the version to be published. All authors have read and approved the final manuscript.

\section{Acknowledgement}

This work was funded by the subsidy allocated to Kazan Federal University for the project part of the state assignment in the sphere of scientific activities (No 04-03/10).

\section{Conflict of Interest}

The authors declared that they have no competing interests.

\section{References}

1. De Jong JW, Van Der Belt-Gritter B, Koeter GH, Postma DS (1997) Peripheral blood lymphocyte cell subjects with chronic obstructive pulmonary disease: association with smoking, IgE and lung function. Respir Med 91: 67-76.

2. Rottem M, Gershwin ME, Shoenfeld Y (2002) Allergic disease and autoimmune effectors pathways. Dev Immunol 9: 161-167.

3. Urboniene D, Sakalauskas R, Sitkauskiene B (2005) [Autoimmunity in pathogenesis of chronic obstructive pulmonary disease]. Medicina (Kaunas) 41: 190-195.

4. Wu B, Ootani A, Iwakiri R, Sakata Y, Fujise T, et al. (2006) T cell deficiency leads to liver carcinogenesis in azoxymethane-treated rats. Exp Biol Med (Maywood) 231: 91-98.

5. Cohen JJ, Duke RC, Fadok VA, Sellins KS (1992) Apoptosis and programmed cell death in immunity. Annu Rev Immunol 10: 267-293.

6. Lenardo MJ, Boehme S, Chen L, Combadiere B, Fisher G, et al. (1995) Autocrine feedback death and the regulation of mature $\mathrm{T}$ lymphocyte antigen responses. Int Rev Immunol 13: 115-134.

7. Bellamy CO, Malcomson RD, Harrison DJ, Wyllie AH (1995) Cell death in health and disease: the biology and regulation of apoptosis. Semin Cancer Biol 6: 3-16.

8. Vodounon AC, Ckibo Y, Aikou N, Akpona S, Abramova ZI, Kotchoni OS, Baba-Moussa L. Morphological and biochemical characteristics of apoptosis lymphocytes of peripheral blood in the pathogenesis of atopic bronchial asthma of light and serious severity. Trade Sci Inc (Res. Rev BioSci) (2012) 6(8): 210- 20.

9. Zhivotovsky B, Wade D, Nicotera P, Orrenius S (1994) Role of nucleases in apoptosis. Int Arch Allergy Immunol 105: 333-338.

10. Szopa J, Adamiec R (1993) Is the $65 \mathrm{kDa}$ protein a direct signal for the nuclease release from nuclear matrix, starting the apoptotic cascade? Acta Biochim Pol 40: 209-212.

11. Vodounon ACJr, Baba-Moussa L, Pynthyk Y, Sezan A, Abramova ZI. The Implication of morphological characteristics in the etiology of Allergic Asthma Disease and in determining the degree of severity of Atopic and Bronchial Asthma. Asian J Cell Biol (2011) 6: 65-80.

12. Nagata S, Nagase H, Kawane K, Mukae N, Fukuyama H (2003) Degradation of chromosomal DNA during apoptosis. Cell Death Differ 10: $108-116$. 
Citation: Vodounon CA, Abramova ZI, Skibo YV, Reshetnikova ID, Akpona SA, et al. (2015) Nuclease Activity Associated with Secreting Granules by Lymphocytes in Patients with Bronchial Asthma. Biol Med (Aligarh) 8: 264. doi:10.4172/0974-8369.1000264

Page 7 of 7

13. Napirei M, Wulf S, Eulitz D, Mannherz HG, Kloeckl T (2005) Comparative characterization of rat deoxyribonuclease 1 (Dnase1) and murine deoxyribonuclease 1-like 3 (Dnase113). Biochem J 389: 355-364.

14. Oliveri M, Daga A, Cantoni C, Lunardi C, Millo R, et al. (2001) DNase I mediates internucleosomal DNA degradation in human cells undergoing drug-induced apoptosis. Eur J Immunol 31: 743-751.

15. Lipskaia LA (1994) [Calcium and magnesium ion-dependent endonuclease $37 \mathrm{kDa}$ is activated during colchicine-induced apoptosis in HL-60 cells]. Tsitologiia 36: 303-309.

16. Meng XW, Fraser MJ, Feller JM, Ziegler JB (2000) Caspase-3 activates endo-exonuclease: further evidence for a role of the nuclease in apoptosis. Apoptosis 5: 243-254.

17. Pio R, López-Zabalza MJ, Rouzaut A, Santiago E, Lopez-Moratalla N (1998) Nitric oxide activates granules-associated DNA in human monocytes. Nitric Oxide 2: 165-73.

18. Barythnikov AY, Shishkin YB (1996) Programmed Cell Death (apoptosis). Russian Oncology J 1: 58-60.

19. National Heart, Blood and Lung Institute. Global strategy for asthma management and prevention (1995) WHO/NHLBI Workshop Report, National Heart, Lung and Blood Institute Publication No. 95: 3659, Bethesda, MD, USA.

20. National Asthma Education and Prevention Program. Expert panel report 2: guidelines for the management of asthma (1997) National Institutes of Health, Publication.

21. Heyfits LB, Abalkin VA (1973) Separation of human blood cells in a density gradient Ficoll-verografin. Lab Work 10: 579-81.

22. Antoneeva II (2007) Differentiation and activation-associated markers of peripheral blood lymphocytes in the patients with ovarian in the course of tumor progression. Med Immunol 6: 649-52.

23. Patel D, Rubbi CP, Rickwood D (1995) Separation of $\mathrm{T}$ and B lymphocytes from human peripheral blood mononuclear cells using density perturbation methods. Clin Chim Acta 240: 187-93.

24. Pollard JW, Walker JM (1989) Animal Cell Culture. In Methods in Molecular Biology. New Jersey: Humana Press, Clifton.

25. Khorshid FA (2005) Comparative study of keloid formation in humans and laboratory animals. Med Sci Monit 11: BR212-219.

26. Khorsid FA, Mushref SS (2006) In vitro Anticancer Agent I-Tissue Culture Study of Human Lung Cancer Cells A549 II-Tissue Culture Study of Mice Leukemia Cells L1210. Int J Cancer Res 2: 330-44.

27. Skibo YV, Vodounon AC, Morozov MV, Koube Bocco SM, Sina H, et al (2102) Adhesion force of T-lymphocytes in the pathogenesis of patients with light and severe bronchial and atopic asthma. Int J Med Res 3: 2138-46.
28. Podack ER, Konigsberg PJ (1984) Cytolytic T cell granules. Isolation, structural, biochemical, and functional characterization. J Exp Med 160: 695-710.

29. Pio R, Gonzalez A, Lopez-Zabalza MJ, Prieto J, Sqntiqgo E, et al. (1998) Granule associated DNase in T4 and T8 lymphocytes from patients with autoimmune diseases. Biochim Biophys Acta 1406: 51-61.

30. Thoma F (1992) Nucleosome positioning. Biochim Biophys Acta 1130: 1-19.

31. Green DR, Scott DW (1994) Activation-induced apoptosis in lymphocytes. Curr Opin Immunol 6: 476-487.

32. Melis M, Siena L, Pace E, Gjomarkaj M, Profita M, et al. (2002) Fluticasone induces apoptosis in peripheral T-lymphocytes: a comparison between asthmatic and normal subjects. Eur Respir J 19: 57-266.

33. Counis MF, Torriglia A (2000) DNases and apoptosis. Biochem Cell Biol 78: 405-414.

34. Shastina BB (2004) Deoxyribonuclease sperm of the sea urchin. Properties specificity and functional role. Abstract for the $\mathrm{PhD}$ degree.

35. Lazarus RA, Wagener JS (2007) Recombinant Human Deoxyribonuclease I". In: Inc IHU, editor. Pharmaceutical Biotechnology. (3rd edn), New York.

36. Boogaard R, de Jongste JC, Merkus PJ (2007) Pharmacotherapy of impaired mucociliary clearance in non-CF pediatric lung disease. A review of the literature. Pediatr Pulmonol 42: 989-1001.

37. Gaipl US, Kuhn A, Sheriff A, Munoz LE, Franz S, et al. (2006) Clearance of apoptotic cells in human SLE. Curr Dir Autoimmun 9: 173-187.

38. Martinez Valle F, Balada E, Ordi-Ros J, Vilardell-Tarres M (2008) DNase 1 and systemic lupus erythematosus. Autoimmun Rev 7: 359-63.

39. Taper HS (2008) Altered deoxyribonuclease activity in cancer cells and its role in nontoxic adjuvant cancer therapy with mixed vitamins $\mathrm{C}$ and $\mathrm{K} 3$. Anticancer Res 28: 2727-32.

40. Nevinsky GA, Kanythkova TG (2002) Natural catalytically active antibodies (abzymes) in health and diseases. J Cell Mol Med 11: 1473-87.

41. Mishra NC (2000) Nucleases: molecular biology and applications. John Wiley \& Sons. 350p.

42. Baranovski AG, Byneva BN, Nevincki GA (2004) Human deoxyribonuclease. Biochemistry 6: 725-742.

43. Khodarev NN, Chupirina IV, Tkacheva TI (1995) Ca, Mg-dependent endonuclease: a putative compton target in cell transformation and death. Cell Proliferat 28: 296-301. 